Arkadiusz Łukasz Fordoński

Uniwersytet Mikołaja Kopernika

\title{
Opinia publiczna wobec planu Balcerowicza
}

\section{Założenia metodologiczne}

Zmiana systemu gospodarczego i politycznego dokonująca się w Polsce na przełomie lat 80. i 90. XX w. zachodziła w niezwykle niesprzyjających warunkach. Niewydolność ekonomiczna państwa, która dla władz Polskiej Rzeczypospolitej Ludowej była jednym z głównych powodów rozmów ze środowiskami opozycji demokratycznej, stała się zaraz po przejęciu rządów podstawowym problemem tej drugiej ${ }^{1}$. W związku z tym uzasadnione wydaje się to, w jaki sposób program stabilizacji gospodarki został przyjęty przez społeczeństw, a także to, jakie czynniki kształtowały poparcie dla niego od momentu jego zainicjowania aż do dymisji realizującego go rządu Tadeusza Mazowieckiego.

W fazie konceptualizacji sformułowano następujący problem badawczy: jaki rezonans spowodował $\mathrm{w}$ opinii publicznej plan stabilizacyjny nazywany powszechnie planem Balcerowicza w okresie jego wprowadzania? Opierając się na zarysowanych poniżej założeniach teoretycznych, sformułowano hipotezę, stanowiącą zakładaną odpowiedź na wyżej postawione pytanie: plan Balcerowicza spotkał się początkowo z przychylnym przyjęciem opinii publicznej, które w miarę jego wprowadzania zmieniło się w niechęć. Za przyjęciem właśnie takiego kształtu głównej hipotezy badawczej przemawiają dwa argumenty zasadzające się na pewnych założeniach apriorycznych:

1. Po pierwsze bardzo prawdopodobne jest to, że skoro stan wyjściowy polskiej gospodarki był niezwykle trudny, wszelkie propozycje zmian mogły budzić nadzieje². Stąd też początkowo plan stabilizacyjny winien być przyjęty przychylnie.

2. Po drugie założenia planu stabilizacyjnego oznaczały szereg przykrych

\footnotetext{
${ }^{1}$ Cf. W. Roszkowski, Historia Polski 1914-2005, s. 79-80, 91-92, 132-133; P. Kowal, Koniec systemu władzy, Warszawa 2012, s.432-440.

2 Nie budził ich niewprowadzony w życie plan rządu Mieczysława Rakowskiego zaprezentowany w lipcu 1989 r., ale ten był w wielu punktach krytykowany przez ekonomistów i nie zdołał zyskać poparcia elit politycznych, cf. D. Zagrodzka, REFOlucja, „Gazeta Wyborcza” 1989, 23 października, nr 119, s. 3. 
konsekwencji dla obywateli ${ }^{3}$. Mechanizmy jego działania nie były jednak zbyt jasne dla osób nie posiadających pewnej wiedzy ekonomicznej, a elit politycznych wprowadzających plan nie powinno interesować przedstawianie jego przykrych konsekwencji ${ }^{4}$, gdyż $\mathrm{w}$ ten sposób przeprowadzenie reform byłoby trudniejsze ${ }^{5}$. Tak więc, dopiero gdy negatywne skutki zaczęły się ujawniać i dotykać poszczególne osoby, ich stosunek do reform musiał się pogarszać.

Mając na uwadze znaczenie oraz mechanikę procesu formowania się opinii publicznej, postawiono także pytanie pomocnicze oraz odpowiadającą mu hipotezę. Pytanie to wydaje się również przydatne $\mathrm{z}$ perspektywy sformułowanego problemu badawczego i brzmi: Jak do planu Balcerowicza odnosiły się elity społeczne, gospodarcze, polityczne i medialne w okresie, gdy był wprowadzany w życie? Odpowiada mu następująca hipoteza badawcza: Elity społeczne, gospodarcze, polityczne i medialne odnosiły się do planu Balcerowicza przychylnie do momentu rozpoczęcia kampanii przed wyborami prezydenckimi, od kiedy to znaczna ich część przeszła do gruntownej krytyki planu.

Drugą z hipotez poddano procedurze badawczej korzystającej z metody analizy dyskursu. Dla falsyfikacji pierwszej posłużono się zarówno metodą analizy dyskursu, jak i metodą analizy danych zastanych. Porządek falsyfikacji hipotez jest odwrotny do kolejności, w jakiej zostały przedstawione powyżej z tego względu, że druga z nich ma charakter pomocniczy.

\footnotetext{
3 Wprowadzenie podatku od ponadnormatywnych wypłat wynagrodzeń, czyli tzw. popiwku, miało zahamować inflację, ale instrumentem służącym temu celowi było zahamowanie wzrostu wspomnianych już w jego nazwie uposażeń. Demonopolizacja przyniosła z kolei - początkowo - powiększenie się grupy bezrobotnych, co było spowodowane restrukturyzacją nieznających dotąd wymogów gry rynkowej zakładów państwowych. W obliczu pojawienia się konkurencji, racjonalizacja zatrudnienia okazała się w nich konieczna. Szerzej na temat skutków społecznych planu w artykule: K. Soroka, Skutki społeczne „planu Balcerowicza" [online], 13 października 2012 [dostęp: 14.04.2014]. Dostępny w internecie: <http://www. polscott24.com.skutki-spoleczne-\%E2\% 80\%9Eplanu-balcerowicza\%E2\%80\%9D>.

${ }^{4} \mathrm{Na}$ temat sposobu prezentacji szans wynikających z planu patrz szczególnie w: $W$ krzyżowym ogniu odpowiedzi, „Gazeta Wyborcza” 1989, 19 grudnia, nr 161, s. 2.

${ }^{5}$ Już wcześniej propozycje zmian spotykały się oporem Ogólnopolskiego Porozumienia Związków Zawodowych, podsycanie niepokojów mogło więc skutkować skoordynowanymi wystąpienia społecznymi, cf. Rada ministrów, „Gazeta Wyborcza” 1989, 3 października, s. 1. Mimo to pojawiały się teksty i wypowiedzi członków Rady Ministrów, a także zaangażowanych po stronie reformy polityków, którzy wskazywali, że przyniesie ona wiele kosztów i na jej pozytywne rezultaty przyjdzie długo czekać, cf. R. Kurkiewicz, Finanse bez pieniędzy. Rozmowa z sekretarzem stanu w Ministerstwie Finansów, dr. Markiem Dąbrowskim, „Gazeta Wyborcza" 1989, 29 września, nr 103, s. 3; opinia ministra Tadeusza Syryjczyka cytowana przez J. Jankowiaka w: J. Jankowiak, Miedzy zamrożeniem a popiwkiem, „Gazeta Wyborcza” 1989, 8 listopada, nr 130, s. 3; R. Przybyłowska, Między popłochem a nadziejq, ,Gazeta Wyborcza” 1989, 12 października, nr 112, s. 6.
} 
Dla odpowiedzi na konstytuujące problem badawczy pytanie konieczne jest zdefiniowanie wzmiankowanego już pojęcia opinii publicznej. Prekursorem badań nad nią był Jan Gabriel Tarde. W toku badań wypracował jej syntetyczne objaśnienie: „Jest to chwilowa, mniej lub więcej logiczna grupa sądów, odpowiadających zagadnieniom doby bieżącej, które w licznych odbitkach kursują wśród ludzi zamieszkujących współcześnie jeden i ten sam kraj, należących do jednej należących do jednej i tej samej warstwy społecznej"6.

Ksiądz Andrzej Zwoliński zwraca uwagę na pochodzenie językowe wyrażenia „opinia publiczna”. Jak wskazuje słowo „opinia” wywodzi się od łacińskiego opinio, czyli pogląd, mniemanie, przekonanie, a więc określa sąd, który nie jest pewny, lecz w jakiejś mierze prawdopodobny. Znaczenie tego terminu nie uległo zmianom pod wpływem czasu, nadal oznaczając przypuszczenie, hipotezę7. Jak dalej wskazuje ksiądz Zwoliński, pojęcie interesujące z perspektywy niniejszych rozważań intuicyjnie można „odnosić do zbiorowych przekonań, wyrażanych przez większe wspólnoty społeczne. Przekonania te są spontaniczne, niejako mechaniczne, zawierają ocenę różnych zachowań, dominującą w danej grupie [...] jest zjawiskiem występującym niezależnie od kultury i czasów, a więc pan kulturowym"8.

Najbardziej bodaj uznany polski badacz tematyki opinii publicznej Eugeniusz Młyniec wraz z Andrzejem Antoszewskim proponują obszerną, kontekstualną definicję interesującego nas pojęcia. Opinia publiczna to według nich:

zmienna forma świadomości dużych grup społecznych wyrażanych w formie ocen, sądów, które dotyczą kwestii istotnych dla systemu politycznego i stosunków pomiędzy rządzącymi i rządzonymi. Warunkiem niezbędnym do pojawiania się opinii publicznej jest zaistnienie kontrowersyjnych zjawisk, możliwość ich wyartykułowania i oceny w sposób werbalny (lub w każdej innej formie), a także (jak to określa w swojej definicji opinii publicznej Hans Speier): «[...] swoboda wyrażanych poglądów». Pojęcie opinii publiczej jest przedmiotowo węższe od pojęcia opinii społecznej, które dotyczy np.: stosunku obywateli do mody, dzieł sztuki czy sposobów odżywiania9.

\footnotetext{
${ }^{6}$ J.G. Tarde, Opinie i tłum, Warszawa 1904, s. 73; cyt. za: A. Zwoliński, Słowo w relacjach społecznych, Kraków 2003, s. 82.

7 Ibidem, s. 80-81.

8 Ibidem, s. 81, cf. M. Iłowiecki, Media, władza, świadomość społeczna, Łódź 1999, 59-60.

9 E. Młyniec, A. Antoszewski, Opinia publiczna [w:] Leksykon politologii, red. A. Antoszewski, R. Herbut, Wrocław 2004, s. 274. 
Młyniec i Antoszewski przywołują więc podstawowe elementy obecne w klasycznej definicji Tarde'a: zmienność i obecność wśród znacznych grup ludzi. Jako pole, do którego odnoszą się wchodzące w ramy opinii publicznej sądy, prezentują sferę polityki. Przyjmując za autorami, że warunkiem pojawienia się opinii publicznej jest „swoboda wyrażanych poglądów”, należy ją powiązać z demokracjami liberalnymi. Stwierdza to wprost w definicji Danuta Radziszewska-Szczepaniak:

\begin{abstract}
Opinia publiczna - poglądy wielkich grup społecznych, ulęgające zmianom pod wpływem czynników ekonomicznych, politycznych i propagandowych, wyrażane publicznie w kwestiach uważanych za kontrowersyjne i ważne dla trwania lub zmiany systemu politycznego. Warunkiem istnienia opinii publicznej jest wolność słowa (publiczne oświadczenia, wypowiedzi w mediach) i zgromadzeń (demonstracje, manifestacje, pochody). Istnieje ścisły związek między opinią publiczną a charakterem systemu politycznego. Systemy autorytarne lub totalitarne nie pozwalają na ujawnienie opinii publicznej. Na opinię publiczną mają wpływ m.in.: wyobrażenia o interesach grupowych, wiedza o faktach, stereotypy, mity i utopie, przesądy i uprzedzenia, pogłoski i plotki. Współcześnie istotną rolę opiniotwórczą pełnią środki masowego przekazu10.
\end{abstract}

Należałoby dokładniej zgłębić, w jaki sposób interesujące nas zagadnienie było przedstawiane przez najpopularniejsze media. Choć zaobserwowanie bezpośredniego wpływu tych relacji na konkretne postawy wydaje się niemożliwe (wskazuje na to powszechne zarzucenie bezpośredniego stosowania założeń paradygmatu behawiorystycznego), widoczne są korelacje między intensywnością prezentowania przez media danego zjawiska oraz obecnym w odpowiednich materiałach stanowiskiem ich twórców wyrażanym często za pomocą zabiegów perswazyjnych.

W mojej opinii sposób kreowania opinii publicznej dobrze wyjaśnia powszechnie znany kaskadowy model Karla Deutscha. Według niego proces tworzenia opinii publicznej zaczyna się w środowiskach elit społeczno-ekonomicznych, stamtąd komunikaty „spływają” do elit politycznych, a następnie za ich pośrednictwem do mediów. Istotnym elementem procesu kreowania opinii publicznej jest też grupa liderów bądź kreatorów opinii, tj. osób społecznie zaangażowanych będących autorytetami w swoich

10 D. Radziszewska-Szczepaniak, Opinia publiczna [w:] Mały słownik politologii, red. S. Opara, Toruń, s. 102. 4 
środowiskach (ze względu na doświadczenie życiowe, wiedzę, pozycję społeczną lub zawodową). Oni odpowiednio komentują informacje docierające za pośrednictwem mediów i przekazują do niższych warstw. Według Deutscha na każdym z tym poziomów może dojść do sprzężeń zwrotnych. Przyjęty kształt hipotez ma w założeniu oddawać mechanikę tego procesu i wskazywać na tendencje, które towarzyszyły ewolucji stosunku opinii publicznej do planu Balcerowicza.

Podstawowym źródłem, na podstawie którego możemy odtworzyć stosunek elit politycznych i medialnych do planu stabilizacyjnego, są świadectwa myśli politycznej: artykuły prasowe i materiały audiowizualne, a także teksty programowe.

\section{Stosunek elit politycznych i medialnych do planu stabilizacji gospodarki}

Hiperinflacja, niewydolność przedsiębiorstw państwowych, brak podstawowych produktów oraz wysokie zadłużenie zagraniczne państwa były dostrzegalne nawet przez laików, stąd też i diagnoza ówczesnego stanu nie była przedmiotem żywszych sporów. Jak zauważyła Danuta Zagrodzka, „Sprawa «ile rynku, ile planu» tak jeszcze kilka lat temu dyskutowana w środowiskach fachowych, przeszła do lamusa"11. Niemal powszechne zarzucenie myśli o reformowaniu patologii systemu gospodarki centralnie sterowanej i zgoda co do potrzeby przejścia do takiego czy innego modelu gospodarki kapitalistycznej nie oznaczały jednak konsensu co do metod, za pomocą których ów model miałby zostać wprowadzony. Program Balcerowicza już w momencie jego omawiania w gronie ekonomistów w Instytucie Finansów spotkał się z szeregiem krytycznych opinii, pośród których sporadycznie tylko pojawiała się całkowita krytyka jego założeń. Dyrektor Instytutu Grzegorz Kołodko nazwał rządowy plan „refolucją”, a więc hybrydą rewolucji i reformy. Wyraził także swój sceptycyzm, jeśli chodzi o możliwość spełnienia założonych celów, tj. stabilizacji gospodarki i zmiany systemu gospodarczego bez użycia w okresie przejściowym nakazów. W jego opinii w innym wypadku groziło Polsce niewystępujące nigdzie indziej zjawisko hiper-shortage inflation, czyli inflacji przy braku wszystkiego. Zauważył także, że szansą dla programu, jest szerokie poparcie społeczne, którego plany reform proponowane przez rząd Mieczysława Rakowskiego nie miały. Podnoszono także

\footnotetext{
${ }^{11}$ D. Zagrodzka, op. cit., s. 3. Potwierdzał to przebieg obrad sejmowych nad planem, podczas których nawet posłowie Polskiej Zjednoczonej Partii Robotniczej nie zgłaszali obiekcji wobec generalnego kursu ku kapitalizmowi, cf. Jesteśmy pragmatyczni nie kapitalistyczni, „Gazeta Wyborcza” 1989, 19 grudnia, nr 161, s. 1. 
temat innych słabości programu. Zarzucano mu, że dąży przede wszystkim do ograniczania popytu, a nie zwiększania podaży, a także iż zaniedbuje wciąż najsilniejszy sektor państwowy. Zwracano uwagę, że szybkie ujednolicenie kursu walutowego doprowadzi do dalszych problemów z inflacją, a także, iż niższy kurs złotówki doprowadzi do zwiększenia kosztów obsługi zadłużenia zagranicznego. Witold Modzelewski postulował, by obok zaprowadzonej już liberalizacji cen, nowy rząd wprowadził liberalizację marż. Wskazywano wreszcie, że system kar za podwyższanie wynagrodzeń jest zbyt restrykcyjny ${ }^{12}$. Mimo tych zastrzeżeń większość ekonomistów zgadzała się z podstawowym założeniem planu, tj. postulatem walki z destabilizującą system inflacją, „nawet za cenę dalszego spadku produkcji, dochodu narodowego, poziomu życia”13. Z całkowitą negacją plan spotkał się natomiast ze strony Aleksandra Jędraszczyka, który na łamach „Polityki” dowodził, że:

Projekt gospodarczych zmian przedstawiony na konferencji prasowej rządu $6 \mathrm{bm}$. to nie zmiana systemu, lecz III etap jego reformy. Różnice między II a III etapem tkwią w językowej warstwie artykulacji. Tradycyjną urzędniczo-ideologiczną nowomowę zastąpiono innym metajęzykiem, konkretnie - aktualnie używanym językiem docentów z kuźni kadr centralnego planisty jakim jest SGPiS [Szkoła Główna Planowania i Statystyki, od 1991 r. Szkoła Główna Handlowa - przyp. aut.].

[...] Projekt pójścia w kierunku wolnej gospodarki jest zbiorem chaotycznych, niespójnych i niekompletnych tez.

[...] Czego brakuje tu z całą pewnością: hamowania finansowego. Państwo wylewa z budżetu rzeki fałszywego pieniądza. [...] Państwo nie chce (nie potrafi?) odebrać bilionów złotych należności od swoich monopolistycznych, które spadkiem produkcji i inflacyjnymi zwyżkami cen ograbiły ludzi. [...] Państwo to nadal toleruje zbrodniczo wysoki kurs dolara, który czyni naszą pracę w kraju bez sensu, a najbardziej aktywnych specjalistów i młodzież zamienia w gastarbeiterów.

[...] Jaka jest zatem główna myśl ekonomiczna projektu: światowe wolne ceny energii i towarów, a płace - wschodnioeuropejskie ${ }^{14}$.

Zamiast planu Balcerowicza Jędraszczyk proponował powtórzenie reform

\footnotetext{
${ }^{12}$ D. Zagrodzka, op. cit., s. 3.

${ }^{13} \mathrm{~J}$. Baczyński, Rok - nie wyrok, „Polityka” 1990, nr 1(1705), s. 1.

${ }^{14}$ Co myślq o programie, „Polityka” 1989, nr 42(1694), s. 4. 
wprowadzonych latem 1948 r. w Bizonii. W jego opinii wprowadzenie całości tamtych regulacji w Polsce mogło zakończyć się powodzeniem ${ }^{15}$.

Program Balcerowicza był też silnie krytykowany przez Józefa Kaletę. Wrocławski ekonomista zarzucał mu:

1. Brak precyzji w opisie sposobu realizacji sformułowanych w nim zadań.

2. Nieoszacowanie kosztów i korzyści reform.

3. Przyjęcie w projekcie, że inflacja na koniec roku wyniesie 900 proc., a w ciągu trzech pierwszych miesięcy 700 proc. W opinii Kalety miało to doprowadzić do erozji poparcia dla rządu Tadeusza Mazowieckiego i, w efekcie, winno skutkować przekreśleniem wysiłków prowadzących do wyprowadzenia kraju z kryzysu.

4. Zastosowanie metod walki $\mathrm{z}$ inflacją będących kontynuacją dotychczasowej nieskutecznej polityki władz. Co więcej, wprowadzenie nowych podatków mające zablokować możliwości wzrostu produkcji nawet w wysoko rentownych gałęziach gospodarki.

Kaleta proponował politykę propodażową opierającą się na założeniu, że duże możliwości znajdują się w poprawieniu jakości produktów konsumpcyjnych, z których ówcześnie znaczna część nie trafiała do punktów sprzedaży z powodu nie spełnienia wymogów. Szansą na zmianę tego stanu rzeczy miało być wprowadzenie „sensowniejszych systemów motywacyjnych i bardziej rygorystyczne egzekwowanie norm technologicznych" 16 . Kaleta przekonywał o potencjale tkwiącym w przestawieniu przemysłu ciężkiego na potrzeby rynku towarów konsumpcyjnych. Jednak oprócz konstruktywnej krytyki, nie wskazał alternatywy.

Koalicja rządząca planu Balcerowicza nie przyjęła bez zastrzeżeń. Stronnictwo Demokratyczne poparłszy plan, zwróciło uwagę na nadal obecny brak równości prawnej sektorów gospodarczych, którego efektem było upośledzenie sektora prywatnego. Ponadto wskazało na podnoszony także przez środowiska ekonomistów „brak zdecydowanej polityki propodażowej rządu", niedostatek działań zmierzających do zatrzymania inwestycji wymagających nakładów materiałowych i energetycznych oraz konieczność doprowadzenia do sytuacji, w której pomoc zagraniczna będzie napływać

15 Ibidem.

16 Ibidem, s. 4. 
bezpośrednio do podmiotów prowadzących działalność gospodarczą ${ }^{17}$. Podczas sejmowej dyskusji nad programem pojawiły się kolejne zastrzeżenia. Poseł Bonawentura Ziemba z PAX-u stawiał szereg pytań, był pełen wątpliwości: „Czy społeczeństwo to zaakceptuje? Czy spadek stopy życiowej nie będzie za duży? Te 20 proc. spadku płacy realnej oznacza przecież średnią, będą więc grupy, które stracą więcej"18. Posłowie Polskiej Zjednoczonej Partii Robotniczej ostrzegali, że kapitalizm ma różne oblicza, oprócz podziwianego, funkcjonującego w państwach zachodnich, istnieje także kapitalizm Trzeciego Świata. Andrzej Bratkowski z tej samej partii proponował, by podzielić plan i budżet na dwie części. Pierwsza, restrykcyjna byłaby nastawiona na walkę z inflacją. Druga, jedynie prognozowana, zostałaby zaprojektowana w szczegółach dopiero w drugiej połowie roku i miałaby zawierać regulacje prowadzące do walki $\mathrm{z}$ niedoborami towarów konsumpcyjnych ${ }^{19}$.

Spośród stanowisk zajmowanych przez ugrupowania pozaparlamentarne warto przedstawić postawę zdecydowanie przeciwnej planowi Balcerowicza Polskiej Partii Socjalistycznej Rewolucji Demokratycznej. Program stanowił zagrożenie wobec głównego celu ugrupowania, tj budowy społeczeństwa bezklasowego. Niemniej jednak nawet nawoływania Józefa Piniora, by opracować program alternatywny dla planu Balcerowicza, nie pomogły partii go wygenerować20.

Rozrzut opinii wśród publicystów był podobny do tego, który można było zaobserwować w gronie polityków i ekonomistów. Znalezienie przykładów całkowitej negacji kierunku reform napotykało trudności, częstokroć pojawiały się jednak zarzuty wobec konkretnych proponowanych przez wicepremiera Balcerowicza rozwiązań.

Wiele wątpliwości wobec planu stabilizacyjnego wykazywała redakcja „Trybuny Ludu”. Waldemar Mickiewicz zarzucał mu przede wszystkim bezradność w obliczu spadku produkcji. Uważał, że ograniczenia płac wprowadzane przez nowy rząd są kontynuacją polityki poprzednich gabinetów, której obecnie rządzący swego czasu się sprzeciwiali. Ponadto był zdania, że budowa funduszu stabilizacyjnego jest dalszym obciążaniem budżetu ${ }^{21}$. Jerzy Bielecki z kolei, wskazując na potrzebę zaakceptowania

\footnotetext{
${ }^{17}$ Mało prywatyzacji i groźne sojusze, „Gazeta Wyborcza” 1989, 22 listopada, nr 140, s. 2.

18 Jesteśmy pragmatyczni..., op. cit., s. 1.

19 Ibidem; $W$ debacie poselskiej nad programem społeczno-gospodarczym rzqdu, „Trybuna Ludu” 1989, 20 grudnia, nr 295(14062), s. 3.

${ }^{20}$ W. Król, Strajk generalny jest naszq jedyna realnq szansq, „Gazeta Wyborcza” 1989, 12 grudnia, nr 155, s. 2.

${ }^{21}$ W. Mickiewicz, Rynkowe wyznanie wiary, Trybuna Ludu" nr 235 (14002), 9.10.1989, s. 3. 
gospodarki rynkowej i zauważając, że wiele rozwiązań zawartych w programie było „wspaniałych”, ubolewał nad przerzucaniem kosztów reformy na barki emerytów i ludzi pracy, a także nad niedostatecznym informowaniem przez rząd o konsekwencjach wdrożenia planu Balcerowicza 22 .

W stonowany sposób o planie wypowiadał się na łamach „Polityki” Jerzy Baczyński. Z jednej strony wyrażał przekonanie, że dzięki niemu skończą się nękające społeczeństwo braki w zaopatrzeniu w towary konsumpcyjne, z drugiej wskazywał, że za sprawą obniżenia płac realnych, nawet przy większej konkurencji na rynku, większość obywateli przez jakiś czas odczuje niedobory w domowych budżetach. Baczyński zwracał też uwagę na ryzyko recesji oraz bankructwa kilkuset zakładów. Gdyby wraz z nią znacznie spadła produkcja, inflacja znów by wzrosła, a tym samym program stabilizacyjny poniósłby porażkę23.

Wprowadzenie planu w życie wywołało tak nadzieję, jak i niepewność wśród przedsiębiorców oraz kadry zarządzającej przedsiębiorstw. Jednym z najpoważniejszych zarzutów wysuwanych z ich strony było nieuwzględnienie w programie instrumentów propodażowych (obniżek podatków), a wręcz działania antypodażowe (podnoszenie danin publicznych). Dostrzegano już wtedy szansę w nowej polityce walutowej, dzięki której otworzyły się szerokie możliwości w zakresie eksportu produktów przetworzonych oraz importu surowców i półproduktów ${ }^{24}$.

Z krytyką działania planu i gospodarczej polityki rządu w ogólności długo nie czekał Waldemar Mickiewicz. W tekście z początku stycznia 1990 r. dostrzegał, co prawda, że na ocenę tej polityki przyjdzie jeszcze czas, zwracał jednak uwagę na to, że część rozwiązań już wtedy nie przyniosła oczekiwanych rezultatów. Zastana przez rząd sytuacja ekonomiczna była lepsza niż po kilku miesiącach jego urzędowania: inflacja była niższa, a produkcja wyższa. Plan Balcerowicza natomiast od samego początku nie funkcjonował odpowiednio. Działo się tak częściowo dlatego, że jego twórcy nie uwzględnili w prognozach zachowań przedsiębiorców. Mickiewicz kpił z tego, że ekonomiczny doradca premiera Waldemar Kuczyński okazywał w mediach rozczarowanie tymi zachowaniami (dalszym windowaniem cen przez przedsiębiorstwa), ponieważ za ich sprawą, w przekonaniu Kuczyńskiego, wprowadzany program napotykał trudności. Co

\footnotetext{
22 J. Bielecki, Ostro do przodu, ale rozsqdnie, „Trybuna Ludu” 1989, 19 grudnia, nr 294(14061), s. 3.

${ }^{23}$ J. Baczyński, Rok nie..., s. 4.

24 J. Solska, A. Mozołowski, Na progu, „Polityka” 1990, nr 2(1706), s. 3. 
więcej, Mickiewicz utrzymywał, że program nie jest dostosowany do polskich warunków społeczno-gospodarczych, a jedynie do wymagań światowej finansjery ${ }^{25}$.

Już od początku plan wpływał niekorzystnie na sytuację materialną rolników, która natychmiast stała się przedmiotem komentarzy liderów opinii. Rolnicy sprzedający pod koniec roku swoje produkty (jak wiadomo rolnictwo jest w znacznej mierze zależne od rytmu narzucanego przez pory roku) otrzymali na tyle niską zapłatę, że gospodarstwa części z nich już wtedy znalazły się poniżej progu opłacalności. Tymczasem korekcyjne podwyżki z początku stycznia zwiększyły znacząco koszty produkcji, tak że poniesione straty postawiły pod znakiem zapytania dalsze zakupy pasz i innych produktów potrzebnych do kontynuowania produkcji. W dodatku, wcześniejsze wydatki inwestycyjne ze względu na nagły wzrost oprocentowania kredytów zaczęły wpędzać co bardziej przedsiębiorczych rolników w jeszcze większe problemy ${ }^{26}$.

Z czasem w środowisku ekonomistów głosy krytyczne wobec planu doprowadziły do pewnych alternatywnych projektów. Marek Gruchelski (ówcześnie pracownik naukowy SGPiS) na początku marca zaczął pozyskiwać poparcie dla swojego projektu (poparcia udzieliła mu NSZZ „Solidarność” Rolników Indywidualnych), który według niego miał spełnić wymogi Międzynarodowego Funduszu Walutowego i - w przeciwieństwie do planu Balcerowicza - dać szansę rozwoju zakładom przemysłowym, spowodować przyspieszenie obrotu kapitału, zlikwidować bezrobocie i zapobiec recesji w produkcji27. W tym samym czasie Kazimierz Łaski (przed 1968 r. prorektor w SGPiS, wówczas profesor zwyczajny na Uniwersytecie Johannesa Keplera w Linzu) wskazywał na nieuchronność niektórych negatywnych skutków programu stabilizacyjnego. Przyjmując podobnie jak Balcerowicz, że należy tłumić popyt, zastanawiał się, czy było konieczne ograniczenie go także przez zmniejszanie wydatków gospodarstw domowych w jego opinii bowiem wystarczające dla zduszenia inflacji byłoby obniżenie inwestycji i deficytu budżetowego. Taka strategia wydawała się uzasadniona nie tylko podnoszonymi przez Łaskiego argumentami natury ekonomicznej („spadek popytu powoduje zwielokrotnione zmniejszenie produkcji”28), ale także możliwością uzyskania społecznego

\footnotetext{
25 W. Mickiewicz, Nad Kreskq i pod kreskq, „Trybuna Ludu”, 6-7,01.1990, nr 5, s. 2.

26 J. Wilczak, Wielkie czekanie, „Polityka” 1990, nr 3, s. 1,6; cf. Śladami stopy życiowej, „Gazeta Wyborcza” 1990, 23 marca, nr 237, s. 3.

27 „Solidarność" rolników ma inny plan, „Gazeta Wyborcza” 1990, 1 marca, nr 218, s. 2.

${ }^{28}$ Recesja przed nami, ibidem, s. 3. 
poparcia 29 .

W miarę pojawiania się kolejnych problemów związanych z wprowadzaniem planu i nowych niekorzystnych zjawisk ekonomicznych dyskusje nad programem Balcerowicza ewoluowały. Z jednej strony zwolennicy planu starali się przezwyciężyć piętrzące się trudności i udowodnić, że w przeważającej mierze nie są one efektem jego działania, z kolei rosnący w siłę przeciwnicy wszystkie problemy ekonomiczne Polski wywodzili wprost od niego i dążyli do złagodzenie jego oddziaływania. Zmieniały się także sojusze, a grono zagorzałych zwolenników planu topniało. W pierwszych miesiącach wdrażania planu zdecydowanie popierała go NSZZ „Solidarność”, której członkowie opowiadali się za unikaniem strajków i prowadzeniem negocjacji oraz „pokojowym współżyciem z konsekwencjami planu”30. Sytuacja zaczęła się jednak zmieniać już w maju 1990 r. W obliczu protestu części niezrzeszonych kolejarzy prezydium Komisji Krajowej NSZZ „Solidarność” wydało 22 maja oświadczenie, w którym zarzuciło rządowi Tadeusza Mazowieckiego „prowadzenie pasywnej polityki gospodarczej, ograniczającej się do kontroli płac, i niepodejmowanie „kroków na rzecz wzrostu produkcji"31.

W marcu propozycję korekty planu Balcerowicza przedstawiło PSL „Odrodzenie”. Jego program opierał się na propozycjach wprowadzenia tanich kredytów inwestycyjnych w rolnictwie i budownictwie mieszkaniowym, zastosowania nowych rozwiązań osłonowych dla najuboższych oraz zmniejszenia podatków ${ }^{32}$.

W miarę pogłębiania się problemów branży rolnej pojawiały się propozycje, by wesprzeć ją dzięki przemodelowaniu polityki państwa. Grzegorz Kuśmierek w „Gazecie Wyborczej" apelował:

Panie ministrze Balcerowicz! [...] Produkcji żywności nie można ani oceniać, ani planować w trzymiesięcznych przedziałach czasu. Musi Pan dokonać natychmiastowej korekty swojego planu w stosunku do finansowania produkcji rolnej. Maszyny rolnicze, nawozy sztuczne już wyprodukowane należy natychmiast dać rolnikom na kredyt, który będzie spłacony przez nich zbożem i żywcem. Nic na tym nie straci «plan Balcerowicza». Należy podjąć natychmiast i to ze

\footnotetext{
${ }^{29}$ Ibidem.

30 Wybory w „Solidarności”, „Gazeta Wyborcza” 1990, 5 lutego, nr 197, s. 2.

31 J. Jankowiak, Rumuni przywożą do Polski konserwy mięsne, wywożą mydło, szampony i ubrania, „Gazeta Wyborcza" 1990, 31 maja, nr 291, s. 5.

32 Bilans nie musi wyjść na zero, „Gazeta Wyborcza” 1990, 14 marca, nr 229, s. 2. 
zdwojoną siłą produkcje maszyn rolniczych i nawozów sztucznych, , «rozdając» je chłopom na tych samych warunkach, to znaczy na spłaty zbożem i żywcem. Ruszy to choć jedną branżę naszego zbankrutowanego przemysłu. Słowo «rozdawać» fatalnie brzmi w Pańskim planie, ale to tylko pozory, gdyż rolnik spłaci to najtrwalszą dzisiaj walutą, bo zbożem i mięsem. Dzięki tym maszynom rolnictwo dogoni inflację, ustali właściwe proporcje cen między maszyną a zbożem. W czasach kiedy 80 proc. zarobków przeznacza się na żywność, kiedy niewielkie nawet wahania podaży tej żywności wywołują natychmiast horrendalne skoki cen żywności, zagwarantowanie sobie dostaw zboża i żywca na lata 1991-1992 to także gwarancja, że «plan Balcerowicza» nie weźmie w łeb jeszcze w roku 1990. Przecież Pan tę najcenniejszą dzisiaj walutę, zboże i żywiec, będzie miał dostarczoną do magazynów i rzeźni bez konieczności drukowania dodatkowych pieniędzy koniecznych na skup płodów rolnych i jego nadwyżek. Pan ten towar kupi już w maju i czerwcu tego roku, a chłop jest solidnym klientem. Proponuję Panu bardzo prymitywną wymianę, ale teraz rolnik już nie pójdzie na żadną inną, bo nie wierzy żadnej walucie, nie wierzy władzy, nie ufa konsumentom. To zaufanie trzeba przywrócić. Walka z inflacją nie może być programem na 10 tygodni. Przed powrotem inflacji należy się zabezpieczyć na całe lata. «Plan Balcerowicza» z czysto teoretycznego dokumentu stanie się skutecznym, konkretnym programem. Te działania musi Pan minister podjąć dziś, natychmiast, bo nie można rządzić krajem bez poparcia rolników ${ }^{33}$.

Propozycji nie poparł rząd, ale jej treść dobrze ukazuje problemy, z jakimi borykało się rolnictwo i pracujący na jego potrzeby przemysł. Na jej podstawie można także odczytać nastroje panujące wśród osób zatrudnionych w tych gałęziach gospodarki. Uderzająca jest w tym kontekście skala braku zaufania do pieniądza pośród rolników. Zastanawia siła, z jaką Kuśmierek formułuje sądy o niezrozumieniu przez władze specyfiki produkcji rolnej - przede wszystkim jej uzależnienia od rytmu pór roku oraz rentowności produkcji rolnej ${ }^{34}$.

Mimo częstej krytyki dostrzegano jednakże sukcesy polityki gospodarczej rządu. Poparcia udzielali jej przedstawiciele międzynarodowej finansjery i światowej sławy ekonomiści (często doradzający polskim władzom) 35. Coraz większa dostępność towarów i spadek stopy inflacji były odczuwane przez społeczeństwo, odnotowywane przez agendy państwowe i komentowane przez polityków i publicystów ${ }^{36}$. Poza tym złagodzeniu

\footnotetext{
33 J. Kuśmierek, Panie Balcerowicz, trzeba ruszyć to koło, „Gazeta Wyborcza” 1990, 13 kwietnia, nr 255, s. 4; Krzyczę, więc jestem!, „Gazeta Wyborcza” 1990, 21 kwietnia, nr 260, s. 11.

34 Cf. J. Kuśmierek, Rewolwer nabity błędami, „Gazeta Wyborcza” 1990, 11 lipca, nr 326, s. 3.

35 Zachodnie opinie o polskich reformach. Dlaczego cud nie jest większy, „Gazeta Wyborcza” 1990, 27 września, nr 392, s. 6.

${ }^{36}$ Cf. Bilans kwartalny, „Gazeta Wyborcza” 1990, 12 kwietnia, nr 254, s. 1. 
społecznego niezadowolenia służyły rozwiązania instytucjonalne i personalne. Wobec postępującej pauperyzacji części społeczeństwa znaczącą rolę odgrywało ministerstwo pracy i polityki socjalnej, na czele którego stał wówczas niezwykle popularny Jacek Kuroń. Jego znaczenie opierało się przede wszystkim na wspieraniu osób znajdujących się w nowej dla nich sytuacji braku zatrudnienia, a także na przeciwdziałaniu wybuchowi społecznego niezadowolenia. Kuroń mówił sam o sobie, że w rządzie odgrywał rolę swoistego „piorunochrona” - swą postawą uwiarygodniał i ochraniał trudny do zniesienia przez społeczeństwo program gospodarczy ${ }^{37}$. Jego niechęć do pozostawiania nierentownych zakładów bez wsparcia państwowego wywoływała jednak konflikty z ministrami resortów gospodarczych ${ }^{38}$.

Ataki na plan Balcerowicza stały się w okresie przed wyborami prezydenckimi jednym z głównych elementów kampanii wyborczej części kandydatów w walce z potencjalnie bardzo groźnym konkurentem w osobie Tadeusza Mazowieckiego. Z tego względu, że program stabilizacyjny stanowił jeden z najważniejszych elementów polityki rządu, któremu przewodził, krytyka planu mogła służyć do jego zdyskredytowania. Zdecydowanymi krytykami planu byli Roman Bartoszcze i Stanisław Tymiński39. Programowi stabilizacyjnemu sprzeciwiały się też tezy programu Leszka Moczulskiego ${ }^{40}$. W sposób wyważony, aczkolwiek krytyczny wypowiadał się o nim Włodzimierz Cimoszewicz ${ }^{41}$, natomiast Lech Wałęsa z pomocą właściwej sobie dialektycznej retoryki zapowiadał, że będzie go kontynuował, ale ze znacznymi korektami ${ }^{42}$. Towarzyszyły temu medialne ataki na plan przedstawicieli sztabu Wałęsy oraz powszechnie znanych jego zwolenników ${ }^{43}$.

Niebagatelną rolę $\mathrm{w}$ uwiarygodnianiu planu w społeczeństwie odgrywały aprobatywne wypowiedzi autorytetów z kręgu światowej finansjery cieszących się dużym społecznym zaufaniem polityków, artystów i innych osób powszechnie znanych, przedsiębiorców, a także uczestników sąd ulicznych. Wielokrotnie cytowała je stanowiąca

\footnotetext{
37 E. Berberyusz, Wizerunki, „Gazeta Wyborcza” 1990, 6 marca, nr 222, s. 4.

${ }^{38}$ Sprawę tę naświetla film: Po prostu Balcerowicz, reż. A. Zajączkowski [Video Studio Gdańsk 1990].

${ }^{39}$ Cf. J. Kwasowski, Kuroń na rolnictwo, „Gazeta Wyborcza” 1990, 2 października, nr 396, s. 2; Jak wyjść z recesji?, „Gazeta Stołeczna” 1990, 20 listopada, nr 437, s. 8.

40 L. Moczulski, Konieczność przełomu [w:] M. Mazur, Marketing polityczny. Studium porównawcze prezydenckich kampanii wyborczych w USA i w Polsce, Warszawa 2007, s. 340.

41 Cimoszewicz zbiera podpisy, „Gazeta Wyborcza” 1990, 18 października, nr 410, s. 3.

42 Cf. Sto pytań do Andrzeja Micewskiego, „Gazeta Stołeczna” 1990, 24 września, nr 389, s. 3; K. Naszkowska, Kogo chca chłopi, „Gazeta Wyborcza” 1990, 29 października, nr 419, s. 10; P. Smoleński, Wałęsa w Radomiu, „Gazeta Wyborcza” 1990, 10 listopada, nr 429, s. 2.

43 S. Kisielewski, Dlaczego Wałęsa, „Gazeta Wyborcza” 1990, 7 listopada, nr 426, s. 11. 
najsilniejszy punkt medialnego zaplecza rządu Tadeusza Mazowieckiego „Gazeta Wyborcza". Jej znaczenie potęgował zespół piszących na jej łamach popularnych dziennikarzy i znaczny nakład ${ }^{44}$. Cytowane w dzienniku przy różnych okazjach wypowiedzi uznanych ekonomistów pozwalały pokazać, że przemiany ekonomiczne w kraju przebiegają zgodnie z planem i oczekiwaniami światowych instytucji finansowych, od których spodziewano się pomocy w restrukturyzacji zadłużenia zagranicznego ${ }^{45}$. Choć trudno wierzyć w to, że artyści mają o zagadnieniach politycznych i ekonomicznych wiedzę większą niż przedstawiciele innych grup społecznych, niejednokrotnie pyta się ich o zdanie w tych odległych od ich codziennej działalności dziedzinach, a także wykorzystuje ich wizerunki do uwiarygodnienia wygłaszanych sądów. Marketing polityczny korzysta z ich poparcia na tyle często, że nazwano to zjawisko terminem „endorsment"46. Powoływanie się mediów na opinie artystów bazuje więc na przekonaniu o ugruntowanej skuteczności tego typu zabiegów. Moim zdaniem odwoływanie się do ich autorytetu w konkretnym, rozpatrywanym przypadku, było dyktowane także przeświadczeniem o pozytywnym stosunku środowisk twórczych do aktualnej ekipy rządzącej - ton poszczególnych wypowiedzi, którego mający rozeznanie w środowisku dziennikarz mógł się spodziewać, jest tego potwierdzeniem ${ }^{47}$. Artyści wygłaszający opinie dla popularnego dziennika w większości wykazywali się przychylnością lub neutralnością do rządu (pogląd radykalnie krytyczny wygłosiła jednak Hanna Krall, co było jednym $\mathrm{z}$ nielicznych przypadków), natomiast wicepremier Balcerowicz i prowadzona przez niego polityka należały do punktów najczęściej komplementowanych ${ }^{48}$. Korzystając $\mathrm{z}$ wypowiedzi potencjalnych pracodawców, dziennikarze wskazywali, że bezrobocie wcale nie jest zjawiskiem negatywnym, a jego znaczny wzrost związany z działaniem planu stabilizacyjnego był mimo wszystko nie tak duży, gdyż rozwijające się przedsiębiorstwa mają problem ze znalezieniem specjalistów, a

\footnotetext{
${ }_{44}$ Pod koniec 1990 r. wynosił średnio około 500 tys. egzemplarzy, cf. [online, pdf] Dostępny w internecie: <http://superbrands.pl/wp-content/uploads/2014/ 03/2005_Gazeta_Wyborcza.pdf> [dostęp: 20.05.2014]. ${ }^{45}$ Cf. J. Kalebiński, Miło, bez konkretów, „Gazeta Wyborcza” 1990, 25 września, nr 390, s. 7.

${ }^{46} \mathrm{Na}$ temat tej techniki cf. M. Mazur, Marketing polityczny. Wyczerpujacy przegląd technik i metod stosowanych w kampanii wyborczej, Warszawa 2002, s. 119-120.

47 Na marginesie można dodać, że istnieją silne przesłanki, by twierdzić, że środowiska artystyczne korzystając z szerokiego mecenatu państwa oraz instytucji od państwa mniej lub bardziej uzależnionych, należą do grup zainteresowanych puryfikacją funkcjonującego aktualnie systemu politycznego, a tym samym wsparciem rządu.

48 Jak rzq̨d rządzi, ankietę przygotowała Anna Bikont, „Gazeta Wyborcza” 1990, 12 sierpnia, nr 379, s. 4-5; J. Stryjkowski, Przygoda z naszym wiekiem, rozm. przepr. R. Przybyłowicz, „Gazeta Wyborcza” 1990, 11 czerwca, nr 300, s. 4.
} 
często jakichkolwiek osób chętnych do pracy nie wymagającej zbyt wielu kompetencji ${ }^{49}$.

Odwoływanie się do autorytetu było tylko jednym spośród środków stosowanych przez „Gazetę Wyborczą”. W tym okresie na jej łamach niejednokrotnie spotyka się przykłady jednostronnego informowania o planie. Czy to w przypadku negocjacji rządu ze związkowcami, podczas których uspokajające apele wicepremiera Balcerowicza zdecydowanie dominują nad potraktowanymi marginalnie wątpliwościami robotników oraz działaczy związkowych ${ }^{50}$. Pojawiały się wreszcie teksty, w których redaktorzy „Gazety” wprost opowiadali się za zmianami wprowadzonymi w ramach programu stabilizacyjnego bądź polemizowali z jego antagonistami. Warto wspomnieć, że Stanisław Remuszko pełen ekspresji sławił sukces Balcerowicza w walce o wymienialność dolara51, a $\mathrm{z}$ kolei Janusz Jankowiak stanowczo apelował do związkowców o przyjęcie odpowiedzialnej postawy i wskazywał na niesłuszność ich postulatów dotyczących poluzowania dyscypliny płacowej52. Joanna Bez dowodziła, że utrzymujące się braki w zaopatrzeniu państwowych sklepów są winą ich dyrekcji, gdyż kredyty staniały, a one dalej nie poszerzają oferty, tkwiąc w przekonaniu, że klient i tak kupi to, co mu zaoferują, a za spadek wolumenu zakupów odpowiada li tylko zwiększenie przez rząd dyscypliny płacowej53. Zbigniew W. Rykowski wskazywał natomiast na potencjalne zagrożenia dla planu wynikające z przyczyn niezależnych od polityki rządu i starał się przedstawić, jak destrukcyjna może okazać się nadmierna bierność społeczeństwa, które w dobrej wierze czeka na ustabilizowanie sytuacji gospodarczej ${ }^{54}$. Michał Ogórek we właściwy sobie sposób z delikatną nutą ironii próbował udowodnić, że pojawiające się wówczas w

\footnotetext{
49 J. Bez, Pełno ich a jakoby nikogo nie było, „Gazeta Wyborcza” 1990, 21 kwietnia, nr 260, s. 6.

${ }^{50}$ Czas Testu, „Gazeta Wyborcza” 1990, 30 marca, nr 243, s. 1.

51 Remuszko dowodził: „już na samym jej starcie coś się Balcerowiczowi udało. Mianowicie: jednym sztychem, precyzyjnie wymierzonym $\mathrm{w}$ zgnile, zielone [pisownia oryginalna, przypis A.F.] serce Zabił Dolara, przygwoździł go do państwowej ceny 9500 zł, i tłumy ludzi z «waszyngtonami» rzuciły się do banków państwowych? sam widziałem! - żeby wynosić stamtąd teczki, chlebaki i siatki pełne złotówek. Cinkciarzy wymiotło, o dla prywatnych kantorów skończył się czas najlżejszego na świecie chleba... Czy Balcerowicz ma równie dobrą rękę w swych innych posunięciach? Oto - na koniec - moja osobista, indywidualna i prywatna wróżbo. Wieszczę, że jeśli tylko nie spadną na Polskę nieszczęścia w rodzaju plag egipskich, Plan Balcerowicza zostanie zrealizowany w 102 procentach: Będzie to osiągnięcie co najmniej na miarę reformy Grabskiego: pełne, oszałamiające i olśniewające. Rozezna, nie w tej kwestii (że się generalnie udało) zyskamy już z przyjściem kalendarzowej wiosny, natomiast całkowitą jasność co do rozmiarów sukcesu przyniesie pierwsza polowa czerwca”, cf. S. Remuszko, Wróżba, „Gazeta Wyborcza” 1990, 3 lutego, nr 196, s. 12.

52 J. Jankowiak, Rumuni przywożą..., s. 5.

53 J. Bez, Negliż okresu przejściowego, „Gazeta Wyborcza” 1990, 7 kwietnia, nr 250, s. 8; cf. E. Skalski, Powtórka z Balcerowicza, „Gazeta Wyborcza” 1990, 16 czerwca, nr 304, s. 6.

${ }^{54}$ Z. Rykowski, Strategia raka. Co słychać?, „Gazeta Wyborcza” 1990, 5 lutego, nr 197, s. 5. 
tytułach prasowych głosy krytyczne wobec planu miały wydźwięk groteskowy ${ }^{55}$. Gdy nawarstwiające się trudności coraz częściej powodowały pojawianie się postulatów korekty planu, Remuszko nawoływał, by dać Balcerowiczowi czas, by dokończył swego dzieła ${ }^{56}$. Dla pełni obrazu należy nadmienić, że ukazywały się w „Gazecie Wyborczej” również artykuły przedstawiające negatywne skutki planu: spadek podaży, dramaty ludzkie wynikające z upadku zakładów produkcyjnych ${ }^{57}$. Te stanowiły jednak na łamach dziennika zdecydowaną mniejszość.

Należy dodać, że obroną posunięć rządu zajmowała się także telewizja publiczna, jednak jej aktywność była po części efektem bezpośrednich nacisków urzędników rządowych. Sprawa stała się na tyle głośna, że nawet prorządowa „Gazeta Wyborcza” poświęciła jej wiele miejsca $\mathrm{w}$ stosownym artykule ${ }^{58}$. Na jej łamach pojawiały się jakkolwiek teksty piętnujące telewizję za zbytni pesymizm w komentowaniu polityki gospodarczej rządu ${ }^{59}$.

\footnotetext{
55 Redaktor Ogórek posłużył się następującą analogią oraz zaskakującym komentarzem: „Należy obawiać się masowego bezrobocia, jeżeli zaopatrywanie przedsiębiorstw w kredyty będzie się odbywało tak, jak to ostatnio zapowiedziano. Przewodniczący związków zawodowych podkreślił, że jeżeli przedsiębiorstwa w związku z reformą walutową zaczną zwalniać robotników, pociągnie to za sobą fatalne następstwa. Znane dotychczas plany reformy podatkowej nie rokują niczego dobrego. W ciągu najbliższych kilku miesięcy to $\mathrm{w}$ wielkim przemyśle oczekiwać należy masowej redukcji robotników. Banki nie dysponują obecnie żadną gotówką. Nic nie wpływa na rachunki bieżące. Reforma skrzywdzi przede wszystkim ludzi pracy. Reforma za jednym zamachem zdezorganizowała cały obrót pieniężny i stworzyła dogodne warunki dla zdominowania wpływów finansjery, głównie amerykańskiej. Na rynku odczuwa się silnie brak środków płatniczych. W ten sposób zamiast dotychczasowej inflacji, pojawiła się deflacja, nadal szkodliwa gospodarczo dla szerokich mas ludności. Można na podstawie kilku faktów sądzić, że ogólnie reforma pieniężna będzie niekorzystna i że same już warunki prawne przedmiotowej reformy wytworzyły sytuację niebezpieczną dla całego systemu państwowego. Jak słychać, manipulacje związane z reformą walutową mogą potrwać aż do 3 miesięcy. Pensje nie będą wypłacane w całości. Napływają doniesienia świadczące z jednej strony o żywym zaniepokojeniu szerokich mas zapowiedzianą reformą, z drugiej zaś o nowej fali spekulacji. Ceny zwyżkują w fantastyczny sposób. Należy liczyć się z ogromnym wzrostem bezrobocia, które może dotknąć około 7 milionów robotników. Już obecnie zamknięto wiele zakładów pracy lub też zredukowano personel. Daje się we znaki spadek produkcji przemysłowej, wynikający z braku kredytów. Wszystkie hotele, restauracje, kina i teatry świecą pustkami. Staje się coraz bardziej widoczne, że reforma pieniężna jest doskonałym interesem dla kapitału zagranicznego. Sprzedaż obligacji bankowych ludności będzie niemożliwa, gdyż ludność nie będzie posiadała gotówki. Wynika z tego, że bankiem zawładnie wielki kapitał zagraniczny. Reforma odbiła się ujemnie na sytuacji gospodarczej ludności pracującej. W bardzo ciężkiej sytuacji znaleźli się również emeryci. Reforma walutowa jest antyspołeczna i kapitalistyczna, i musi zakończyć się klęską. Takie były w 1948 roku oficjalne reakcje prasy polskiej („Głos Ludu”, „Życie Warszawy”, „Życie Gospodarcze”) na wprowadzenie w życie reformy gospodarczej Ludwiga Erharda w Niemczech Zachodnich. Jak świadczy ten przykład? Nie może być bardziej pomyślnej prognozy dla planu Balcerowicza od tego, co obecnie można wyczytać w gazetach.”, cf. M. Ogórek, Prognozy, „Gazeta Wyborcza” 1990. 11 lutego, nr 202, s. 13.

${ }^{56}$ Cf. S. Remuszko, Cierpliwości..., „Gazeta Wyborcza” 1990, 6 kwietnia, nr 249, s. 3.

57 Cf. I. Śledzińska, P. Patora, Widmo taczki, „,Gazeta Wyborcza”1990, 9 lutego, nr 201, s. 6.

${ }^{58}$ A. Bikont, Wiadomości, „Gazeta Wyborcza” 1990, 20 stycznia, nr 184, s. 1, 6.

${ }^{59}$ T. Bogucka, GORLIWOŚĆ NEOFITY czyli telewizja zmienia skórę, „Gazeta Wyborcza” 1990, 10 marca, nr 226, s. 7.
} 


\section{„Plan Balcerowicza” w badaniach opinii publicznej}

Przedstawiwszy obraz planu stabilizacyjnego w myśli politycznej i ekonomicznej, należy przejść do rozważań dotyczących zmian rozkładu opinii na jego temat w społeczeństwie. W styczniu 1990 r., a więc w pierwszych dniach wprowadzania programu stabilizacyjnego, $\mathrm{w}$ opinii publicznej dominowało mniej lub bardziej zdecydowane przyzwolenie na jego wdrażanie. Na pytanie: „Czy program Balcerowicza jest jedynie słuszny?" 19 proc. respondentów odpowiedziało, że to „jedyne co nam pozostało”, 16 proc., iż to „jedyny program, który zadowoli tych, co nam pożyczyli i mogą jeszcze pożyczyć pieniądze", 14 proc. wybrało odpowiedź sugerującą, że plan Balcerowicza był „najlepszym w tej chwili sposobem poprawy gospodarki”, 20 proc. uważało, iż jest to „jeden z możliwych sposobów naprawy gospodarki”, dla 5 proc. był to „jeden z gorszych sposobów", zaś 26 proc. stwierdziło, że trudno powiedzieć, czy był słuszny60. Zdecydowany sprzeciw wobec planu wyrażała więc bardzo mała część społeczeństwa. Dominujące wśród osób zdecydowanych poparcie dla programu było jednak motywowane najczęściej nie jego niekwestionowaną atrakcyjnością, ale raczej przekonaniem, że może spełnić swoją funkcję lub realistyczną oceną trudnej sytuacji gospodarki. Z kolei na pytanie "Gdybyś był posłem głosowałbyś [za:...]” 35 proc. respondentów odpowiedziało, że „za najszybszą realizacją programu Balcerowicza”, 33 proc. „za realizacją, ale rozłożoną w czasie”, 13 proc. „za skierowaniem do ponownego opracowania”, 9 proc. „za odrzuceniem i opracowaniem konkurencyjnego programu”, na opcję "trudno powiedzieć" zdecydowało się 10 proc. procent badanych ${ }^{61}$. Decyzja parlamentu o wprowadzeniu planu w życie zaraz po jej podjęciu była więc bardzo silnie legitymowana przez społeczeństwo - 68 proc. społeczeństwa opowiedziało się za wprowadzeniem planu. Sposób jego wprowadzenia nazwany „terapią szokową” cieszył

\footnotetext{
${ }^{60}$ CBOS, Społeczna ocena i przewidywane następstwa programu Balcerowicza, Warszawa, 1990, styczeń, cyt. za: B. Chochołowski, Czy warto było wprowadzać program Balcerowicza [online], 5 stycznia 2010 [dostęp: 20.05.2014]. Dostępny

w internecie: <http://www.money.pl/gospodarka/raporty/artykul/czy;warto;bylo;wprowadzac;program;balcerowicza,1 $68,0,572840 . h t m l>$. Pewne zastrzeżenia budzi dobór alternatyw odpowiedzi, nie tworzą one bowiem wyczerpującego zbioru (dla przykładu brak odpowiedzi: Plan jest najgorszym możliwym sposobem reformy gospodarki, a możliwe byłoby pokrywanie się pewnych preferencji - np.: Plan jest dlatego jedynym co nam pozostało, ponieważ to jedyny program, który zadowoli tych, co nam pożyczyli i mogą jeszcze pożyczyć pieniądze. To z kolei mogło powodować pewien zamęt myślowy u respondentów i wzrost odsetek odpowiedzi „trudno powiedzieć”). Możliwe, że lepszym rozwiązaniem byłoby zastosowanie bardziej klasycznego wariantu skali Likerta.
}

61 Ibidem. 
się jednak poparciem jedynie nieco ponad połowy zwolenników programu.

Wykonawcy planu cieszyli się znacznym, bo sięgającym 64 proc. poparciem opinii publicznej, a co więcej zanim negatywne efekty planu dały się odczuć, większość społeczeństwa miała świadomość, że okres przemian nie będzie łatwy: „87 proc. spodziewało się pogorszenia warunków życia, z czego 79 proc. uważało, że pogorszenie będzie trwało długo, a aż 85 proc. spodziewało się, że znacznego obniżenia poziomu życia"62. W mojej opinii miało to bardzo duże znaczenie, gdyż chroniło rząd przed wybuchem społecznego niezadowolenia, który mógł być gwałtowniejszy, gdyby rozbudzono nadzieje na szybką poprawę sytuacji bytowej.

Ilustracja 1.

Źródło: CBOS, Społeczna ocena i przewidywane następstwa programu Balcerowicza, Warszawa, 1990, styczeń, cyt. za: B. Chochołowski, Czy warto było wprowadzać program Balcerowicza [online], 5 stycznia 2010 [dostęp: 20.05.2014]. Dostępny $\mathrm{w}$

internecie: <http://www.money.pl/gospodarka/raporty/artykul/czy;warto;bylo;wprowadzac;program;balcerowicza,168,0,57284 $0 . h$ tml $>$.

Jak widzimy, poparcie dla planu z czasem zaczęło słabnąć, co prawdopodobnie było powodowane wzrostem bezrobocia oraz - przede wszystkim - spadkiem siły

62 B. Chochołowski, Czy warto było wprowadzać..., op. cit. 
nabywczej wynagrodzeń. Spiralę spadku zaufania wobec planu nakręcały zapewne także wybuchy publicznego niezadowolenia skierowane przeciw niemu (osoby niezadowolone nie bały się deklarować swoich preferencji, widząc, że nie są w tym osamotnione - na przeciwników planu przestawało oddziaływać zjawisko spirali milczenia) ${ }^{63}$. Choć wcześniejsze badania opinii publicznej wskazywały, że społeczeństwo było przygotowane na wyrzeczenia, zetknięcie $\mathrm{z}$ realnymi problemami sprawiło, że wcześniejsze deklaracje gotowych na pogorszenie się warunków życia zwolenników reformy okazały się krótkotrwałe. Spadkowi poparcia dla planu towarzyszyło - rzecz jasna - zwiększanie się grupy jego przeciwników, lecz nie było ono wprost proporcjonalne ze względu na wzmiankowany wzrost liczby osób niezdecydowanych. W moim przekonaniu, taka sytuacja była spowodowana brakiem dostatecznych informacji na temat planu. Rząd i jego stronnicy zbyt mało miejsca poświęcali tłumaczeniu społeczeństwu, w jaki sposób działanie planu przekłada się na aktualną sytuację ekonomiczną, $\mathrm{z}$ drugiej zaś strony zinstytucjonalizowane podmioty przeciwne programowi bądź opowiadające się za jego korektą wykładały swoje racje w sposób dość niejasny, nie przedstawiając w istocie konkretnej alternatywy dla niego.

\section{Zakończenie}

Swoistym plebiscytem, w którym ogół posiadających prawa wyborcze mógł wyrazić swój stosunek do reformatorskiej polityki rządu, w tym programu Balcerowicza urastającego do pierwszoplanowej roli $\mathrm{w}$ tej polityce, były wybory prezydenckie. Choć ich wyniki trudno bezpośrednio przełożyć na poparcie dla planu - o decyzji, czy poprzeć danego kandydata decydował szereg różnych czynników w znacznej mierze odległych od kwestii programowych - pewne tendencje wskazują na siłę środowisk wprost opowiadających się za planem oraz tych, które konstruowały swój przekaz kampanijny, kontestując go. Z tej perspektywy szczególnie istotne wydaje się poparcie, jakie uzyskali urzędujący wówczas premier Tadeusz Mazowiecki oraz zdecydowany przeciwnik planu Stanisław Tymiński. Prezes Rady Ministrów zdobył w wyborach głosy 2973264 osób, tj. 18,08 proc. głosów ważnych, natomiast na polonijnego biznesmena głosowało 3797605 osób, co stanowiło 23,10 proc. głosów ważnych ${ }^{64}$. Biorąc pod uwagę nawet niedostatki

\footnotetext{
${ }^{63}$ Na temat protestów rolniczych cf. Możemy przegrać, „Gazeta Wyborcza” 1990, 19 marca, nr 232, s. 3.

64 Obwieszczenie Państwowej Komisji Wyborczej z dnia 10 grudnia 1990 i wyniki wyborów Prezydenta 19
} 
kampanii szefa rządu, powyższe wyniki wskazują, że elektorat niezadowolonych był w tym czasie znaczący, a wokół samego właściwie sprzeciwu wobec reform można było sformułować ofertę programową przekonującą dla znacznej części wyborców65. Wydaje się więc, że trudności ekonomiczne towarzyszące wprowadzaniu planu, a także jego krytyka w okresie kampanii prezydenckiej silnie nadwątliły społeczne zaufanie do niego. ibidem, s. 180 . 